\title{
The Impact of Social Networking Usage on Consumer Buying Behavior of College Students in China
}

\author{
Ting Liu \\ University of Electronic Science and Technology of China, Chengdu, China
}

\begin{abstract}
This research focused on the impact of social networking usage on consumer buying behavior of college students in China. Using a sample of 195 questionnaires, this research analyzed gender, age related to the choice of social networking site; the type of product purchased, the cost of the item if college students under the impact of social networking sites; and the feature of the students who can be affected easily by different social networking sites.
\end{abstract}

Keywords: social networking site, consumer buying behavior, college students

\section{Introduction}

A social networking service is a platform to build social networks or social relations among people who, for example, share interests, activities, backgrounds, or real-life connections. Most social network services are web-based and provide means for users to interact over the Internet, such as e-mail and instant messaging. According to the investigation of CNNIC, in $2011,26.3 \%$ of social networks users talked about enterprise brand and product information and $20.5 \%$ of all respondents referred to the comments on social networks to help themselves to consume commodities and make purchase decision ${ }^{[1]}$; in $2012,44.8 \%$ of all users paid attention to brand or commercial homep- age, $43.1 \%$ of all users would have the thought of purchase if they saw the recommendations from friends, at the same time, $38.3 \%$ of all users referred to the comments from friends in social networks before purchasing ${ }^{[2]}$. It is easy to know that social networking sites have the significant function of oral spreading from the data provided.

According to 2012's survey from CNNIC, the brand communication and consumption stimulation in social media were more useful for people who were highly educated than others. And high proportion of students in a college level course and above among social networks' users and consumers purchase online illustrates that college students have noteworthy impact on the development of social networks and e-commerce. Hence, this paper investigating the impact of social networking on consumer buying behavior from the point of college students would make some sense.

In 2012, Mathur Pooja analyzed questions like the membership status in several social-media sites and the frequency of visiting to these sites as well as the frequency with which selected opinions were expressed during these visits and provided preliminary statistical evidence to evaluate the relationship between social media usage and the overall impact social-media marketing has on purchase behavior $^{[3]}$. Lukas P. Forbes investigated the types and characteristics of products that are being recommended and pur- 
chased by social media users ${ }^{[4]}$. Pingjun Jiang reported that if consumers had positive attitudes towards marketing communication at social networking sites, consumers were more likely to attend the advertised information ${ }^{[5]}$.

There are not many papers focus on the relationship between social network and college students to explore if the price and type of products (e.g. clothing, tickets) or services involved in a potential purchase are different in social networking sites separately. The object of study in this paper is college students, key researches include the type and price group of commodities involved in a potential purchase in several famous social networking sites, the purchasing process and so on.

\section{Methodology}

The study based on questionnaires published on sojump.com, a professional questionnaire survey website, opening to college students in all over the China. From the survey, 195 completed responses were received. $62 \%$ of the respondents were boys. Students in bachelor degree accounted for $69.74 \%$. Thus, the respondents in the 21-23 age group accounted for largest percentage. In addition, there were more students majored in engineering and management than others, with the rate of $29.74 \%$ and $27.18 \%$ respectively. There was a small group students' pocket money in the group of 1501 RMB and above. But large proportion was in the group of 501-1000 RMB. 33.33\% of all respondents have purchased online more than 10 times in half a year.

In this survey, social networking sites include Weibo (e.g. Sina, Tencent, etc.), Renren, Douban, Kaixin, QQ Space, Twitter and "other". According to the data from Internet, in 2013, the amount of users of Renren, Douban and Kaixin all exceeded 1 hundred million. At present, there are more than 8 hundred million Weibo users. Mathur Pooja pointed out that Twitter had higher influence than other sites and it also had a large amount of users. Hence, Twitter included. Also, what should be pointed out is that the choices of "interested contents while using social networking sites" based on the contents of Renren, QQ Space and so on, including communicating with friends, commercial information (e.g. product, works, industry), entertainment (e.g. food, sports, etc.), social issues, educational information and "other". For the commodities in survey, there were 13 categories in total, according to survey result from CNNIC ${ }^{[6]}$.

Lucid Marketing Survey found that $68 \%$ of individuals consulted friends and relatives before purchasing home electronics $^{[7]}$. To find that if advertisement or recommendation has impact on college students' buying behavior, this survey based on papers from Lukas P. Forbes, Mathur Pooja and K. Burke set four factors. They are advertisements on social networks, purchase or recommendation from friends, friends' comments and strangers' comments.

Specifically, key questions in questionnaire including:

- What contents did college students interested in while using social networks?

- How often did college student use social networks and how much did four factors on social networking site influence students' interest in commodities?

- What type of commodity did students would buy if they were affected by social networking? What was the commodity price ranges?

- How was the commodity purchased by college students? 
All data came from the analysis result of sojump.com, correlation analysis and cross-over analysis included.

\section{Analysis}

\subsection{Basis information}

Robert Miller hold the view that main ways students used social networking sites include staying in contact with old friends, checking pictures and connecting with students in a class ${ }^{[8]}$. His point supported by this survey. It was clear that high proportion of college students were interested in communicating with friends and entertainment. The next was social issues.

It was pointed out in Tab. 1 that college students focused on entertainment and communication while they spend some time on social information. There were limited tendency on other ways.

Tab. 1: the contents college students were interested in

\begin{tabular}{|c|c|}
\hline Category & $\begin{array}{c}\text { Percentage of re- } \\
\text { sponse }\end{array}$ \\
\hline Entertainment & $76.96 \%$ \\
\hline $\begin{array}{c}\text { Communicating } \\
\text { with friends }\end{array}$ & $73.82 \%$ \\
\hline Social issues & $50.26 \%$ \\
\hline $\begin{array}{c}\text { Commercial infor- } \\
\text { mation }\end{array}$ & $21.47 \%$ \\
\hline $\begin{array}{c}\text { Educational infor- } \\
\text { mation }\end{array}$ & $19.90 \%$ \\
\hline Other & $14.66 \%$ \\
\hline
\end{tabular}

A less surprising result was the social networking sites students used. $65.29 \%$ of all respondents used Weibo while this figure was $75.13 \%$ in QQ Space usage. Renren came to the third, with the figure of $48.2 \%$. The result came from other choices was less than $30 \%$ in total. That means, QQ Space, Weibo and Renren had high popularizing rate among college students.

\subsection{The influence from gender, edu- cation level, age and pocket mon- ey on the choice of social net- working sites}

A surprising result was gender had limited impact on the choice on social networking site but education level did. The popularizing rate of QQ Space was higher than Weibo among undergraduates while it was opposite among master. Interestingly, the popularizing rate of QQ Space kept decreasing while the figure of Weibo kept rising among students with junior college education, undergraduates and master. The rate of Renren reached its peak at the group of undergraduates.

By contrast, students in 27-29 age group were likely to use QQ Space with the popularizing rate of $100 \%$ while the figure of Weibo in 30 and above age group was $100 \%$ as well. What should be pointed out is that the popularizing rate of Renren had positive correlation with pocket money. For all respondents, QQ Space got the highest frequency of visiting and Weibo came to second followed by Renren.

\subsection{The impact from social network- ing sites}

For influence, the hierarchy was interval scale variables which range from 1-5, with 5 being the deepest influence and 1 being no effect. For the users of QQ Space and Weibo, they believed friends' comments would have the deepest degree of influence while strangers' comments came to second, according to Tab.2. When it came to Renren, friends' comments also played an important role. Clearly, four factors mentioned had an impact on college students' buying behavior but do not have obvious difference.

For pocket money, it was found that the users of QQ Space who's pocket money under 500 RMB or 1501 RMB and above affected by this site easily while the corresponding pocket money 
Tab. 2: Mean hierarchy of effects of four factors in three social networking sites

\begin{tabular}{|c|c|c|c|c|}
\hline Category & $\begin{array}{c}\text { Advertisements on } \\
\text { social networks }\end{array}$ & $\begin{array}{c}\text { Friends' com- } \\
\text { ments }\end{array}$ & $\begin{array}{c}\text { Strangers' } \\
\text { comments }\end{array}$ & $\begin{array}{c}\text { Purchase or rec- } \\
\text { ommendation } \\
\text { from friends }\end{array}$ \\
\hline QQ Space & 2.26 & 2.98 & 2.53 & 2.26 \\
\hline Weibo & 2.26 & 2.71 & 2.36 & 2.33 \\
\hline Renren & 2.22 & 2.54 & 2.20 & 1.95 \\
\hline
\end{tabular}

group was 1001-1500 RMB. By contrast, the students' pocket money between 501 and $1000 \mathrm{RMB}$ were hardest to be affected among Renren users. Considering all data, students who tended to be affected easily by social networks on their buying behavior usually had limited pocket money (under $500 \mathrm{RMB}$ ) or reasonable pocket money (between 1001 and 1500 $\mathrm{RMB})$.And the opposite group was 5011000 RMB.

From the perspective of times shopping online in half a year, college students in the 7-10 times group were impacted by social networks easier compared with others. Apparently, it was hard to effect students who did not buy anything online in half a year.

On the other hand, over half of students selected clothing and shoes if they bought something online under the influence of social networks, according to Tab.3. At the same time, over $40 \%$ of respondents pointed out that the things they would buy under the influence were commodities in 101-300 RMB price group. The next were commodities in 50$100 \mathrm{RMB}$ price group. Interestingly, the commodities with low cost (under 50 RMB) and high cost (over 500 RMB) had low rate, with the figure of $11.98 \%$ and $10.11 \%$ respectively.

This research also investigated if "clicking through" was useful for students. It was not surprising that only $4.1 \%$ of respondents would purchase commodities by "click through". Instead, most students $(71.28 \%)$ would purchase commodities through a more familiar website and a small group of students
$(17.95 \%)$ would choose the websites their friends recommended.

Tab. 3: The type of commodity students would buy under the impact from social networking

\begin{tabular}{|c|c|}
\hline Category & $\begin{array}{c}\text { Percentage of } \\
\text { response }\end{array}$ \\
\hline Clothing and shoes & $65.43 \%$ \\
\hline $\begin{array}{c}\text { Books and audiovisu- } \\
\text { al products }\end{array}$ & $33.51 \%$ \\
\hline Living goods & $32.98 \%$ \\
\hline 3C products & $24.47 \%$ \\
\hline Catering services & $24.47 \%$ \\
\hline Bags & $20.21 \%$ \\
\hline $\begin{array}{c}\text { Electrical equipments } \\
\text { except 3C }\end{array}$ & $18.09 \%$ \\
\hline Tickets & $17.55 \%$ \\
\hline $\begin{array}{c}\text { Foods and health care } \\
\text { products }\end{array}$ & $17.02 \%$ \\
\hline $\begin{array}{c}\text { Stationeries and } \\
\text { sporting goods }\end{array}$ & $15.43 \%$ \\
\hline Cosmetics & $14.36 \%$ \\
\hline Rechargeable cards & $13.30 \%$ \\
\hline Other & $13.30 \%$ \\
\hline
\end{tabular}

\section{Conclusion}

To sum up, QQ Space has the priority among social networking sites for college students in terms of popularizing rate and usage frequency. That mean, QQ Space might be the most useful advertisement marketing for advertiser and investor. According to table 2, QQ Space really has superiority on affecting college students' buying behavior.

The results from questionnaires also point out that comments viewed on social networking site affect students most. This indicates that for some online stores aiming at college students, getting positive 
comments from customers would has positive impact on exploiting potential consumers.

Obviously, pocket money would affect the influence of social networking sites on buying behavior. Also, students in different pocket money group would be affected by social networks differently in disparate degree. Hence, adviser should choose specific social networking site according to target-consumer. Further, QQ Space and Weibo are both useful. Besides, not any kind of commodities fit advertising online for college students. Clothing and shoes may be more available.

Although Mathur Pooja pointed out that more influence was induced when the price of commodities involved in a potential purchase is more expensive and Mathur Pooja hold the view that consumers were easy spurred by the quick and easy purchase also. But in this survey, students are easy influenced on purchasing while commodities in 101-300 price group. The result may be explained by the particularity of college students. They can make purchase decision quickly if commodities are reasonable, and commodities with high cost are unaffordable.

Naturally, there are some issues in questionnaire and analysis. For example, the questions requesting information regarding how a student believes he or she has been impacted in their purchase behavior by social networking sites may not be easy to capture accurately. Also, a limited number of students joined in this survey.

\section{References}

[1] CNNIC, "2011 Chinese netizens social networking applications research report," China Internet Network Information Center, 2012.

[2] CNNIC, "2012 Chinese netizens social networking applications research report," China Internet Network Information Center, 2012.

[3] M. Pooja, B. Jennifer E.,C.Jiangmei, B. Paul D.,W. Bruce D., "The Impact of Social Media Usage on Consumer Buying Behavior," Advances In Management,vol.5,issue.1, pp.14-22, 2012.

[4] L. P. Forbes, E. M. Vespoli, “Does Social Media Influence Consumer Buying Behavior? An Investigation Of Recommendations And Purchases," Journal of Business \& Economics Research, vol. 11,Number 2,pp.107111,2013

[5] P. Jiang, "Determinants of participant's responses to marketing communications on social networking sites," Journal of the Academy of Business \& Economics, Vol. 13 Issue 1 , pp.61-78,2013

[6] CNNIC, "2012 China's online shopping market research report," China Internet Network Information Center, 2013.

[7] K. Burke, "As consumer attitudes shift, so must marketing strategies," Twelfth ACM Conference on Electronic Commerce (EC'11), pp. 157166, 2003.

[8] R. Miller, K. Parsons, D. Lifer, "Students and social networking sites: the posting paradox," Behavior \& Information Technology, Vol. 29, No.4, pp.377-382, 2010. 